\title{
EFFECT OF SUBCUTANEOUS ZERANOL IMPLANTS ON MEAT QUALITY OF AWASSI LAMBS AND CROSS-BRED KHALKHALI AND ABADEH GOAT KIDS
}
S. H. Al-doski ${ }^{1}$
H. F. Kak ${ }^{2}$
J. S. Khurshid ${ }^{3 *}$
F. Vriesekoop ${ }^{4}$
V.J. Taha ${ }^{3}$
Lecturer
Assist. Lecturer
Lecturer
Prof.
Lecturer

${ }^{1}$ Duhok Technical Institute DPU, ${ }^{2}$ Technical College-Akre, Duhok Polytechnic University, ${ }^{3}$ College of Agricultural Engineering Science, University of Duhok, Duhok, Iraq, ${ }^{4}$ Department of Food Technology \& Innovation, Harper Adams University, UK, * Corresponding author: Jamal-sadeek@uod.ac.

\section{ABSTRACT}

This experiment was conducted to evaluate the effects zeranol implant on meat quality of Awassi lambs and cross-bred Khalkhali and Abadeh goat kids. Ten ram lambs $(33.7 \pm 0.5 \mathrm{~kg}$ and 4-month-old) and ten male goat kids $(18.8 \pm 0.7 \mathrm{~kg}$ and 4-month-old) were randomly assigned into two treatments (5 each treatment); $C$ (control, $0 \mathrm{mg}$ zeranol) and $\mathrm{Z}(24 \mathrm{mg}$ zeranol implant) for each species. After 43 days experimental period. The animals were slaughtered, left for $24 \mathrm{hr}$ post-mortem period and Biceps femoris muscle of each species were separated for measuring the proximal composition, TBARS values, cooking loss, drip loss and free fatty acids concentrations. Zeranol implants had significant $(P<0.05)$ effect on dry matter, but did not have any effect on all other meat characteristics. However, dry mater was significantly higher for zeranol-implanted group as compared with control one. Moreover, significant effect of animal species was found for cooking loss, being highest in goat meat than ram lamb meat. Similarly, significant effect of animal species was noticed on TBARS values being highest in ram lamb meat. An obvious increase $(P<0.005)$ in drip loss and TBARS values were observed for meat of both zeranol-implanted and non-implanted groups with storage period. It can be concluded that zeranol implant did not have any effect on meat quality for both ram lambs and male goat kids' meat.

Keywords: drip loss, ram lambs, goat kids, zeranol, meat, TBARS, fatty acids , dry matter.

$$
\begin{aligned}
& \text { مجلة العلوم الزراعية العراقية -2021 52 (5):1093-1084) الدوسكي وآخرون } \\
& \text { تاثير حقن الزيرانول في نوعية لحوم ذكور الحملان العواسية و جدايا الماعز المحلي المضرب الخلخالي × العبادي }
\end{aligned}
$$

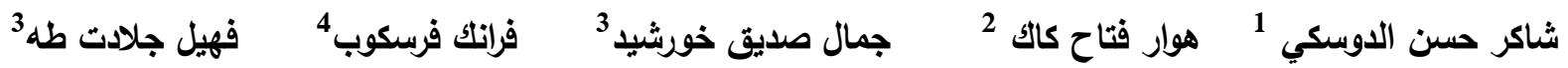

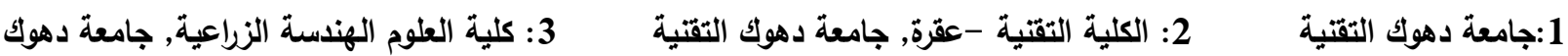

$$
\begin{aligned}
& \text { 4: قسم الاغذية, جامعة هابرادمس, بريطانيا }
\end{aligned}
$$

اجريت هذه الدراسة لدراسة تاثير حقن الزيرانول على نوعية اللحوم لاى الحملان العواسي وذكور جذاء الماعز المحي المضرب

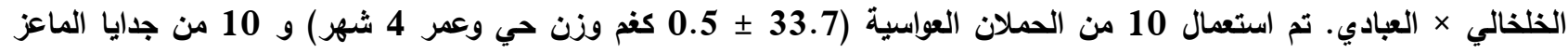

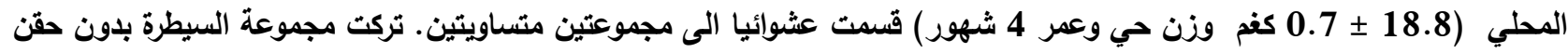

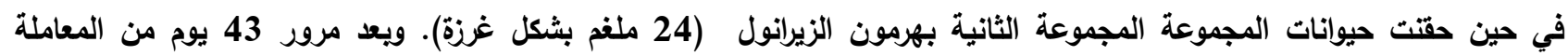

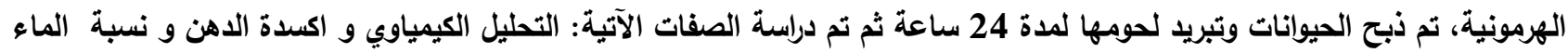

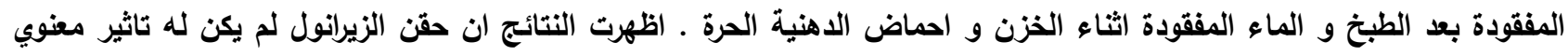
على معظم صفات اللحم بأسثناء زيادة المادة الجافة بنسبة 5 \% . كما كانت اكسدة الدهن اعلى ولعاء معنويا في لحوم حملان العواسية مقارنة بلحوم جدايا الماعز الاسود بنسبة 5 \%. يمكن الاستنتاج ان حقن الزيرانول (24 ملغم لكل حيوان) لم يكن له تاثير على نوعية و صفاء صات اللحم في كل من لحوم الحملان العواسية و جدايا الماعز الاسود. كلمات مفتاحية: حملان, جدايا الماعز, الزيرانول, اللحوم 


\section{INTRODUCTION}

Sheep and goat production are rapidly developing among farmers in the broader Kurdish region in both commercial and smallscale farms (25). Both species are considered the most important farm livestock in Iraq and considered the main source of income for Iraqi farmers (2). Lamb and goat meat production and subsequent consumption have increased significantly due to an increased interest in this kind of meat (21). Recently, farmers have been seeking a better price for their animals to improve profitability. Improvements in profitability are pursued through shorter production periods and lower feed cost (24). Shorter production periods have been pursued through the use of growth promoters (31). There is a range of growth promoters available on the market; these vary from enzyme supplementation in feed, to the prophylactic use of antibiotics, probiotics, herbal metabolic stimulants, and the use anabolic steroids. The use of feed enzymes aid in the overall digestibility of feed which can yield an improved utilisation of nutrients (22). while on the other side of the scale anabolic steroids can be used to increase the growth rate and nutritional efficiency (13, 14). Anabolic steroids have been reported that the utilization of anabolic steroid implants offers the greatest rate of profitability identified with expanding efficiency outside of giving the most satisfactory feeding to beef cattle (26). Hence, application anabolic steroid implants increased about 10 to $21 \%$, average daily gains and enhance feed: gain proportions in feedlot cattle by 6 to $14 \%$ (7). In addition, anabolic implanting tends to decrease fat deposition, resulting in declined marbling scores and reduced thickness of fat. It has been observed that zeranol implants is capable of modifying some of the fatty acid composition in meat (31), particularly polyunsaturated fatty acid content including n-3 and $n-6$ fatty acids, in both, intramuscular and subcutaneous fat tissues. An increasing polyunsaturated fatty acid is very important to human health (18) which have a great biological and cellular functions including producing of prostaglandins, improving of immune function, and organization of response to potential pain and inflammation (10).
However, these are considered more susceptible to oxidative reactions which adversely influence the sensorial attributes of meat through the formation of lipid oxidation by-products such as hydroperoxides, malondialdehyde, 4-hydroxynonenal and volatile compounds (19). These lipid oxidation by-products are responsible for undesirable tastes, flavours, odours and discolouration of meat (23) and can cause a reduction in the nutritional value by the degradation of essential fatty acids (19). Several studies have been applying zeranol as an anabolic agent in feedlots that have shown increases in weight gain and enhances characteristic of carcass quality $(18,7,2)$. However, to our knowledge, the effects of zeranol implants on the meat quality of sheep and goats in terms of changes in the physicochemical and chemical variables is not well documented. Thus, increasing meat yield by this mean without taking meat quality and consumer appeal in consideration is questionable. Meat quality is necessary to be evaluated. Therefore, the main purpose of this study was to address the use of zeranol implantations under common small-scale farming, pastured, practices, and the subsequent lamb and goat meat quality.

\section{MATERIALS AND METHODS}

\section{Experimental animals and design}

The experiment included two species of animals (Awassi lambs and cross-bred Khalkhali and Abadeh goat kids) and two treatments. Each species consisted of 10 male group, where males of Awassi lambs with 33.7 $\pm 0.5 \mathrm{~kg}$ of live weight and 4 months of age, while, males of local cross-bred Khalkhali and Abadeh goat kids with $18.8 \pm 0.7 \mathrm{~kg}$ of live weight and 4 months of age. Each group of animals were randomly divided into two equal treatments. The treatments were: $\mathrm{C}$ (control, 0 $\mathrm{mg}$ zeranol) and $\mathrm{Z}$ (24 $\mathrm{mg}$ zeranol). The zeranol tap was implanted subcutaneously as two $12 \mathrm{mg}$ implants, one behind each ear, making up the $24 \mathrm{mg}$ for 42 days.]. All animals received similar diet while grazing on a lush local pasture. Water was available as ad libitum and refreshed daily. Following 43 days treatment period, the animals were slaughtered according to the procedures legislated by Kurdistan government and the average slaughter weights of animals were $23.15 \pm 0.5$ 
and $39.65 \pm 0.5 \mathrm{~kg}$. At 24 hours post-slaughter, the carcasses were dissected and the Biceps femoris (BF) muscles removed and vacuum packed and immediately frozen at $-20{ }^{\circ} \mathrm{C}$. The samples were transferred to the Meat Products Laboratory located at Animal Production Department, College of Agricultural Engineering Sciences for analysis.

\section{Materials}

\section{Chemical composition of zeranol implants}

Zeranol ((Ralgro® Implants for Beef Cattle, California, US), potassium hydroxide, Ethanol, Chloroform, Malonaldehyde bis (diethyl acetal), Hydrochloric acid, trichloroacetic acid, Acetic acid, Petroleum ether, Sodium hydroxide, Sulphuric acid, Boric acid (Scharlab S. L, Sentmenat, Spain) and 2Thiobarbituric acid, phenolphthalein, Sodium thiosulfate, potassium iodide from Chem-Lab NV, Zedelgerm, Belgium)

\section{Preparation of samples}

This experiment was designed as factorial design consisted of a $2 \times 2 \times 3$ with two species (lamb and goat), two treatments (zeranol treated and non-treated control), and three storage times (0, 4 and 8 days). For the preparation of meat samples, Biceps femoris muscle samples were thawed overnight at refrigeration temperatures $\left(4-5^{\circ} \mathrm{C}\right)$. All meat samples were then stored in polyethylene bags and refrigerated at $4{ }^{\circ} \mathrm{C}$ for 0,4 , and 8 days, the meat samples were taken at each point of storage period and analysed as outlined below.

\section{Proximate analysis}

Biceps femoris muscle of each individual animals was minced by grinder (Heilbron powder grinder model watt HN1019, Germany). Chemical composition of minced meat was measured according to the procedures described in AOAC (3). Dry matter of muscle samples was measured utilizing an oven drying method; meat samples were dried at $60^{\circ} \mathrm{C}$ in an oven for $72 \mathrm{~h} \mathrm{AOAC} \mathrm{(3).} \mathrm{Protein}$ component was determined utilizing a Kjeldahl Analyzer and to calculate the protein content a conversion factor of $6.25 \mathrm{~g}$ of nitrogen/gram of protein was used AOAC (3). Total fat content was determined using Soxhlet extraction AOAC (3). Ash content was measured by burning dried meat in a $550^{\circ} \mathrm{C}$ muffle furnace for $3.5 \mathrm{hrs}$ AOAC (3).

\section{Thiobarbituric Acid Reactive Substances} (TBARS) Determination

TBARS value was meaured in meat samples according to the procedure initially described by Buege and Aust (8). Roughly $0.5 \mathrm{~g}$ of ground meat was weighed and put in a $10 \mathrm{ml}$ test tube to which $2.5 \mathrm{ml}$ of TBA stock solution was added. Samples were then vortexed for $15 \mathrm{sec}$ before being placed in a 95 ${ }^{\circ} \mathrm{C}$ water bath for $15 \mathrm{~min}$, after which the tubes were rapidly cooled down and centrifuged $(\mathrm{K}$ Centrifuge PLC Series, Taiwan) at $2500 \mathrm{~g}$ for $10 \mathrm{~min}$. The supernatant was transferred to a cuvette and the absorbance determined by spectrophotometer (Jenway, 6300 spectrophotometers, UK) at $532 \mathrm{~nm}$ against a blank. The TBARS in meat samples was determined and expressed as $\mathrm{mg}$ of malondialdehyde equivalents / $\mathrm{kg}$ meat using an appropriate malondialdehyde standard curve.

\section{Drip Loss}

Drip loss of meat was determined according to the method described by Honikel (17). Approximately $80 \mathrm{~g}$ of meat was weighed and placed individually into a netted bag and then suspended inside an airtight plastic container at $4{ }^{\circ} \mathrm{C}$. After $24 \mathrm{~h}$ the meat samples were removed and dried using paper towel and reweighed. This represented the ' 0 day' results. The same procedure was used at days 4 and 8. Subsequently, the drip loss was calculated using the following formula: Drip loss $(\%)=[($ Initial weight of raw meat $(\mathrm{g})-$ final weight of meat $(\mathrm{g})$ )/ Initial weight of raw meat $(\mathrm{g})] \times 100$.

\section{Cooking Loss}

Approximately $100 \mathrm{~g}$ of raw meat was weighed and wrapped with aluminium foil before being cooked in an oven at $160{ }^{\circ} \mathrm{C}$ until the internal temperature reached $71^{\circ} \mathrm{C}$ (approximately 10 minutes) as measured with a digital calibrated thermometer (ThermoPro TP025 thermometer, UK). After the cooking process, the meat was cooled to ambient temperature $\left(23^{\circ} \mathrm{C}\right)$. The meat samples were then blot-dried with paper towel and reweighed. Cooking loss was calculated using the following formula:

Cooking loss $(\%)=[($ Initial weight of raw meat - weight of cooked meat)/ Initial weight of raw meat] $\times 100$ 


\section{Free fatty acid value}

Free fatty acid (FFA) value was measured according to the procedure of Rukunudin et al. (26). Approximately $2.5 \mathrm{~g}$ of meat sample was mixed with $15 \mathrm{~mL}$ chloroform by means of a homogenizer for $1 \mathrm{~min}$, after which the mixture was filtered using Whatman number-1 filter paper. Five drops of $1 \%$ ethanolic phenolphthalein as indicator were added to 10 $\mathrm{mL}$ of the filtrate and titrated with a $0.01 \mathrm{~N}$ ethanolic potassium hydroxide solution. The FFA value was determined using the following formula:

Free fatty acid $($ FFA $\%)=[((\mathrm{mL}$ of titration $\times$ Normality of $\mathrm{KOH} \times 28.2)$ )/ (Initial weight of meat sample $(\mathrm{g}))] \times 100$

\section{Statistical Analysis}

All data were analysed using Genstat (GenStat version 17, VSN International Ltd, UK). The data of TBARS value and drip loss of meat were analysed using factorial design of a $2 \times 2$ $\mathrm{x} 3$ where the three factors were the animal species (lambs and goats), treatments (animal implanted with zeranol and control), and three storage periods $(0,4$ and 8 days), with statistical general model as follow:

\section{$Y \mathbf{i j k l}=\boldsymbol{\mu}+\mathbf{A i}+\mathbf{B j}+\mathbf{C k}+\mathbf{A B C}+\mathbf{e i j k}$}

Where: Yijkl is the observation value of the animals, $\mu$ is the overall mean, Ai is the effect of zeranol implantation, $\mathrm{Bj}$ is the effect of animal species, $\mathrm{Ck}$ is the effect of storage period, $A B C$ is the interaction between zeranol implantation and animal species and eijk is the experimental error. The parameters (cooking loss, approximate analysis, free fatty acids) were analysed using two-way analysis of variance (ANOVA). The experiment was conducted in triplicate $(n=3)$. When the main factors and interactions was significant, Tukey's HSD test was used to identify the significant differences between means and the significance level of all data was set at $\mathrm{p} \leq$ 0.05 .

\section{RESULTS AND DISCUSSION}

The results of proximate analysis of the meat from lamb and goat kids treated with zeranol and those without zeranol treatment are presented in Table (1). Non- significant differences were detected between species (lambs and goats) for dry matter, fat, protein and ash contents of the meat (Table 1). However, the percentages of all parameters, with exception of crude protein, were found to be higher in meat from lamb compared to the meat from goat. The mean values for the dry matter, fat, crude protein and ash components were 25.80 and $25.18 \%, 5.02$ and $4.03 \%$, 20.27 and $21.42 \%$, and 1.11 and $1.10 \%$ for the goat and lamb meat samples respectively. These results were similar to values stated in the literature for goats and lamb's meat (27; 29). However, the current results were lesser than those reported by (6). Excluding data of dry matter, the proximate composition, did not significantly affected by the treatment and there were no significant interaction among factors (Table 1). These findings were consistent with those reported by Xiong et al (33) who pointed out that proximate chemical composition of semimembranosus muscle from steers implanted with zeranol did not differ from those unimplanted with zeranol. Furthermore, the fat content observed in the present study for meat of both species were similar to those reported by Vestergaard et al. (30), who found that fat content of meat from steers and heifers was not affected by subcutaneous injections of growth hormone like a pituitary-derived bGH (15-20 mg).

\section{Effect of zeranol implant on lipid oxidation (TBARS value)}

The lipid oxidation (TBARS value) of the biceps femoris muscle in goat kids and lambs either implanted with zeranol or not are noticed in Table (2). As compared with goat kids, Awassi lambs exhibited a significantly $(\mathrm{p}=0.001)$ higher level of TBARS values $(0.99$ and $0.67 \mathrm{mg} \mathrm{MDA} / \mathrm{kg}$ meat) for lamb's and goat kids' meat respectively. This might be due to the fact that lamb meat had higher intramuscular fat than goat meat (4). TBARS is a secondary lipid oxidation product generated from the decomposition of hydroperoxides and considered a good indicator of oxidation status (19). An increase of TBARS in meat is indicative of advanced lipid oxidation (5). Elevated levels of TBARS are associated with off-odours and off-flavours which have a negative effect on sensory properties of meat (9), and as such decreases the shelf-life and nutritional values of meat (19).However, the effect of zeranol implants on TBARS value in muscle of both animal species was not significant $(\mathrm{p}=0.144)$. 
Elevated values of TBARS were detected in meat of unimplanted animals compared to zeranol-implanted animals (Table 2). After the meat samples of both species were subjected to a storage period for 8 days, regardless of animal species and treatments, storage time had a significant $(p=0.002)$ impact on TBARS value. The TBARS value was 0.73 $\mathrm{mg} / \mathrm{kg}$ meat at day 0 , and decreased to 0.69 at day 4, while it markedly increased to 1.07 $\mathrm{mg} / \mathrm{kg}$ meat at day 8 (Figure 1). The increasing in TBARS values on day 8 is a good indicator of occurring lipid oxidation which may be associated with decomposition of hydroperoxides and formation secondary lipid oxidation products such as malondialdehyde during storage period (5). similar phenomenon was detected in goat and lamb's meat (12).

Table 1. Proximate analysis of meat (\% fresh weight basis) for Awassi lambs and goat kids $($ Mean \pm SE) .

\begin{tabular}{|c|c|c|c|c|c|c|c|}
\hline \multirow[t]{2}{*}{ variables } & \multirow[t]{2}{*}{ Species } & \multicolumn{2}{|c|}{ Treatment } & \multirow[t]{2}{*}{ s.e.d } & \multicolumn{3}{|c|}{$p$ value } \\
\hline & & Control & Zeranol & & Species & Treatment & Inter $\mathbf{S} \times \mathbf{T}$ \\
\hline \multirow{2}{*}{ Dry matter (\%) } & Goat & 25.24 & 26.37 & 1.081 & 0.440 & 0.023 & 0.222 \\
\hline & Lamb & 23.61 & 26.76 & & & & \\
\hline \multirow[t]{2}{*}{ Fat (\%) } & Goat & 5.01 & 5.02 & 0.943 & 0.178 & 0.441 & 0.450 \\
\hline & Lamb & 3.50 & 4.57 & & & & \\
\hline \multirow[t]{2}{*}{ Protein (\%) } & Goat & 20.07 & 20.47 & 2.172 & 0.476 & 0.489 & 0.655 \\
\hline & Lamb & 20.51 & 22.33 & & & & \\
\hline \multirow{2}{*}{$\operatorname{Ash}(\%)$} & Goat & 1.06 & 1.16 & 0.0658 & 0.849 & 0.084 & 0.979 \\
\hline & Lamb & 1.06 & 1.15 & & & & \\
\hline
\end{tabular}

Table2. Effect of subcutaneous implants of zeranol on TBARS value (mg MDA/kg meat) of A wassi lambs and goat meat during storage period at $4{ }^{\circ} \mathrm{C}(\mathrm{Mean} \pm \mathrm{SE})$.

\begin{tabular}{|c|c|c|c|c|c|}
\hline \multirow{3}{*}{$\begin{array}{l}\text { Main factors } \\
\text { Animal species (AS) }\end{array}$} & \multicolumn{3}{|c|}{$\begin{array}{c}\text { TBARS value } \\
\text { (mg MDA/kg meat) }\end{array}$} & \multirow[t]{2}{*}{ SED } & \multirow[t]{2}{*}{$\begin{array}{c}\mathbf{p} \\
\text { value }\end{array}$} \\
\hline & Goat & Lambs & & & \\
\hline & 0.67 & 0.99 & & 0.086 & 0.001 \\
\hline \multirow{3}{*}{ Treatment (T) } & Control & Zeranol & & & \\
\hline & 0.89 & 0.76 & & 0.086 & 0.144 \\
\hline & & Storage period & & & \\
\hline Storage period (SP) & $\begin{array}{c}0 \\
0.73\end{array}$ & $\begin{array}{c}4 \\
0.69\end{array}$ & $\begin{array}{c}8 \\
1.07\end{array}$ & 0.106 & 0.002 \\
\hline Interaction AS x T & \multicolumn{2}{|c|}{ Treatment } & & & \\
\hline Goat & 0.74 & 0.59 & & 0.122 & 0.795 \\
\hline Lamb & 1.04 & 0.93 & & & \\
\hline Interaction AS x SP & \multicolumn{3}{|c|}{ Storage period (days) } & & \\
\hline Goat & 0.49 & 0.55 & 0.96 & 0.149 & 0.452 \\
\hline Lamb & 0.96 & 0.83 & 1.18 & & \\
\hline \multirow[t]{2}{*}{ Interaction $\mathrm{T}$ x SP } & \multicolumn{3}{|c|}{ Storage period (days) } & & \\
\hline & $\mathbf{0}$ & 4 & 8 & & \\
\hline Control & 0.77 & 0.77 & 1.14 & 0.150 & 0.940 \\
\hline Zeranol & 0.68 & 0.61 & 1.00 & & \\
\hline
\end{tabular}

Effect of zeranol implant on drip loss /water holding capacity

The drip loss of the biceps femoris muscle in goat kids and lambs either implanted with zeranol or not are observed in Table (3). There was non- significant effect of animal species and treatment on drip loss proportion of meat. Moreover, drip loss was lower in animal implanted with zeranol compared to those unimplanted with mean values of $4.86 \%$ and $4.52 \%$ for control and zeranol treatment (Table 3). Drip loss is shown to be inversely proportional to water-holding capacity (15).
Drip loss can be defined as water losing in meat during the storage period or following a cooking process (1), which is mainly dependent upon the capability of myofibrillar protein to retain and bind water (32). Hence, proteins of meat like fat, undergo-oxidation process by a free radical mechanism (15). These values were in contrary in terms of statistically aspects to those obtained by (11), who found that the water holding capacity of the two muscles Longissimus dorsi and Biceps femoris of lambs was affected significantly by the zeranol implants $(\mathrm{P}<0.05)$ which in both 
muscles, a higher water holding capacity and less drip loss were observed in the muscles from implanted animals compared to the control group. Furthermore, regardless of animal species and treatments, storage time had a significant $(\mathrm{p}<0.001)$ influence on drip loss (Table 3). Meanwhile, the drip loss of meat from both implanted and unimplanted group of animals significantly $(P<0.005)$ increased with storage period. An elevating of drip loss in both group of meat during storage period is more likely returns to more oxidation of meat protein, which could decrease the capability of proteins to hold water. Khurshid (19) reported that meat exhibited the largest percentage of drip loss is considered an undesirable impact on meat quality. According to the results reported by Wang et al. (32), sarcoplasmic and myofibrillar protein solubility in meat decreased with an increase in time. Similar findings were reported by Maqsood, et al. (20), who found progressively an increase of drip loss in camel meat under refrigeration temperature with increasing storage time. Non-significant animal species $\mathrm{X}$ treatment $\mathrm{x}$ storage period interaction for drip loss $(\mathrm{p}=0.879)$ were detected in meat (Figure2). However, drip-loss in all samples increased with increasing the storage periods.

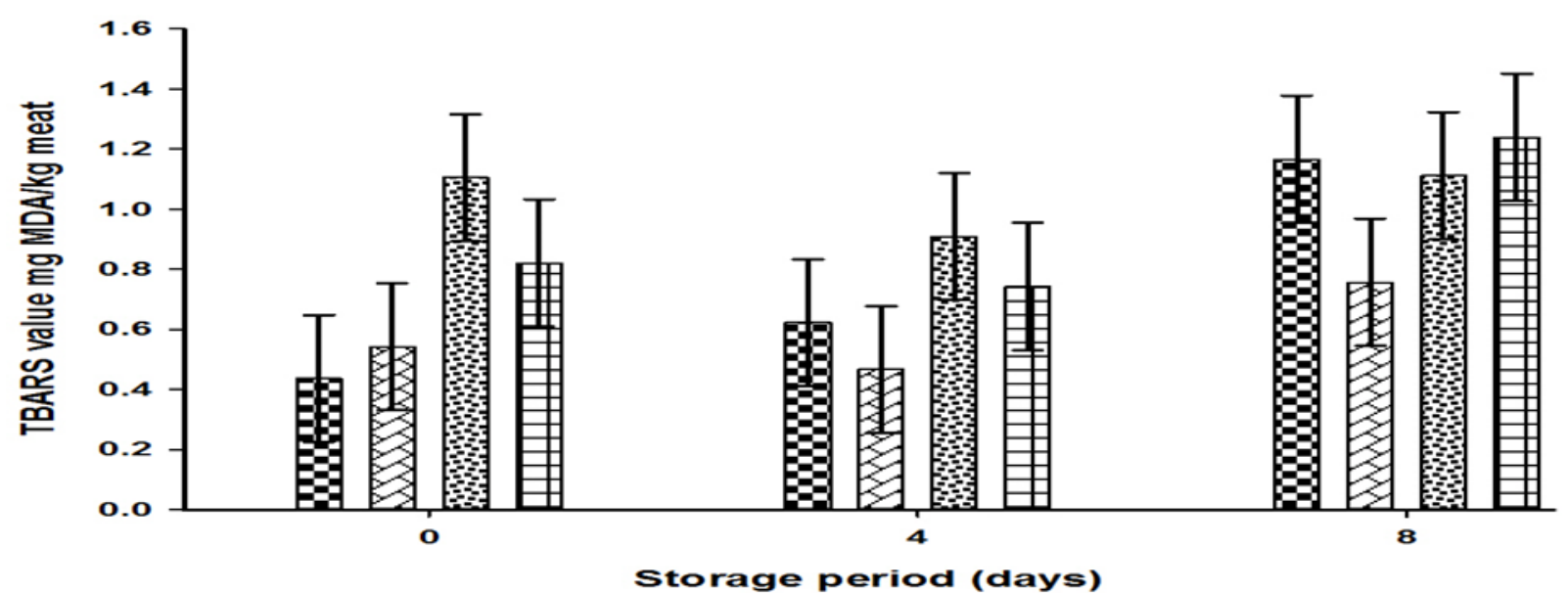

Figure 1. Interaction between subcutaneous implants of zeranol and storage period in Awassi lambs and goat meat., goat control (without zeranol) ( $B \times)$, goat kids with zeranol ( $\square \times \square)$;

Lambs control ( average and standard errors of differences of means

Table 3. Effect of subcutaneous implants of zeranol on drip loss (\%) of Awassi lambs and goat meat during storage period at $4{ }^{\circ} \mathrm{C}($ Mean $\pm \mathrm{SE})$.

\begin{tabular}{|c|c|c|c|c|c|}
\hline \multirow[b]{2}{*}{ Main factors } & \multicolumn{2}{|c|}{ Drip loss (\%) } & & \multirow[t]{2}{*}{ SED } & \multirow[t]{2}{*}{ p value } \\
\hline & Goat & lambs & & & \\
\hline Animal species (AS) & 4.72 & 4.66 & & 0.263 & 0.824 \\
\hline \multirow[t]{2}{*}{ Treatment (T) } & Control & Zeranol & & & \\
\hline & 4.86 & 4.52 & & 0.263 & 0.206 \\
\hline \multicolumn{6}{|c|}{ Storage period (days) } \\
\hline \multirow[t]{2}{*}{ Storage period (SP) } & $\mathbf{0}$ & 4 & 8 & & \\
\hline & 2.47 & 4.18 & 7.43 & 0.323 & $<0.001$ \\
\hline \multirow[t]{2}{*}{ Interaction AS x T } & \multicolumn{2}{|c|}{ Treatment } & & & \\
\hline & Control & Zeranol & & & \\
\hline Goat & 4.87 & 4.58 & & 0.373 & 0.853 \\
\hline Lamb & 4.86 & 4.47 & & & \\
\hline \multirow[t]{2}{*}{ Interaction AS x SP } & \multicolumn{3}{|c|}{ Storage period (days) } & & \\
\hline & $\mathbf{0}$ & 4 & 8 & & \\
\hline Goat & 2.59 & 4.10 & 7.47 & 0.456 & $<0.001$ \\
\hline Lamb & 2.34 & 4.25 & 7.40 & & \\
\hline \multirow[t]{2}{*}{ Interaction T x SP } & \multicolumn{3}{|c|}{ Storage period (days) } & & \\
\hline & $\mathbf{0}$ & 4 & 8 & & \\
\hline Control & 2.64 & 4.43 & 7.52 & 0.456 & 0.879 \\
\hline Zeranol & 2.29 & 3.93 & 7.35 & & \\
\hline
\end{tabular}




\section{Effect of zeranol implant on cooking loss}

The drip loss of the biceps femoris muscle in goat kids and lambs either implanted with zeranol or not are showed in Table (3). Hence, regardless of zeranol implants cooking loss were significantly affected by animal species $(\mathrm{p}<0.001)$. Hence, highest proportion of cooking loss was detected in goat kids' meat $(27.82 \%)$ compared to the Awassi lamb's meat (16.36\%), respectively (Figure 3). Meat of unimplanted goat kids' group had highest percentage of cooking loss following by implanted goat meat, implanted Awassi lambs and unimplanted Awassi lamb's meat with mean values of 30.60, 25.04, 18.63 and 14.08 $\%$ respectively (Figure 3 ). Cooking loss is known total loss of water that occurred in meat during the cooking process and have been linked to the thermal process $(1 ; 16)$, which denature and oxidize protein (32). Thus, reducing the ability of the meat proteins to retain water (1). Furthermore, the proportion of cooking loss of meat from both Awassi lambs and goat kids statistically did not affected $(p=0.289)$ by zeranol implants. These results are consistent with those reported by Thompson et al. (28), who notifying that implanting heifers and steers with growth promoter Revalor-S. (28 mg oestradiol and $140 \mathrm{mg}$ trenbolone acetate) resulted nonsignificantly effect on cooking loss, however, they found that implanted animals had slightly higher cooking loss than unimplanted group of animals. Similar findings were reported by Vestergaard et al. (30), who found that cooking loss of heifer's meat was not affected by subcutaneous injections of growth hormone like a pituitary-derived bGH $(15-20 \mathrm{mg})$ during the breeding. Stability of lipid during the storage period. Figure (4) showed that the free fatty acids were not significantly affected by animal species $(p=0.071)$, while there was a trend of an increasing the amount of free fatty acid in Awassi lamb's meat compared to the goat kids' meat with mean values of 0.35 and $0.44 \%$ for goat and Awassi lamb's meat respectively. These slightly elevated free fatty acids were detected in Awassi lambs could be due high fat content. Moreover, nonsignificant differences were found between implanted and unimplanted animals for both species with zeranol in respect of free fatty acids content in meat (Figure 4).

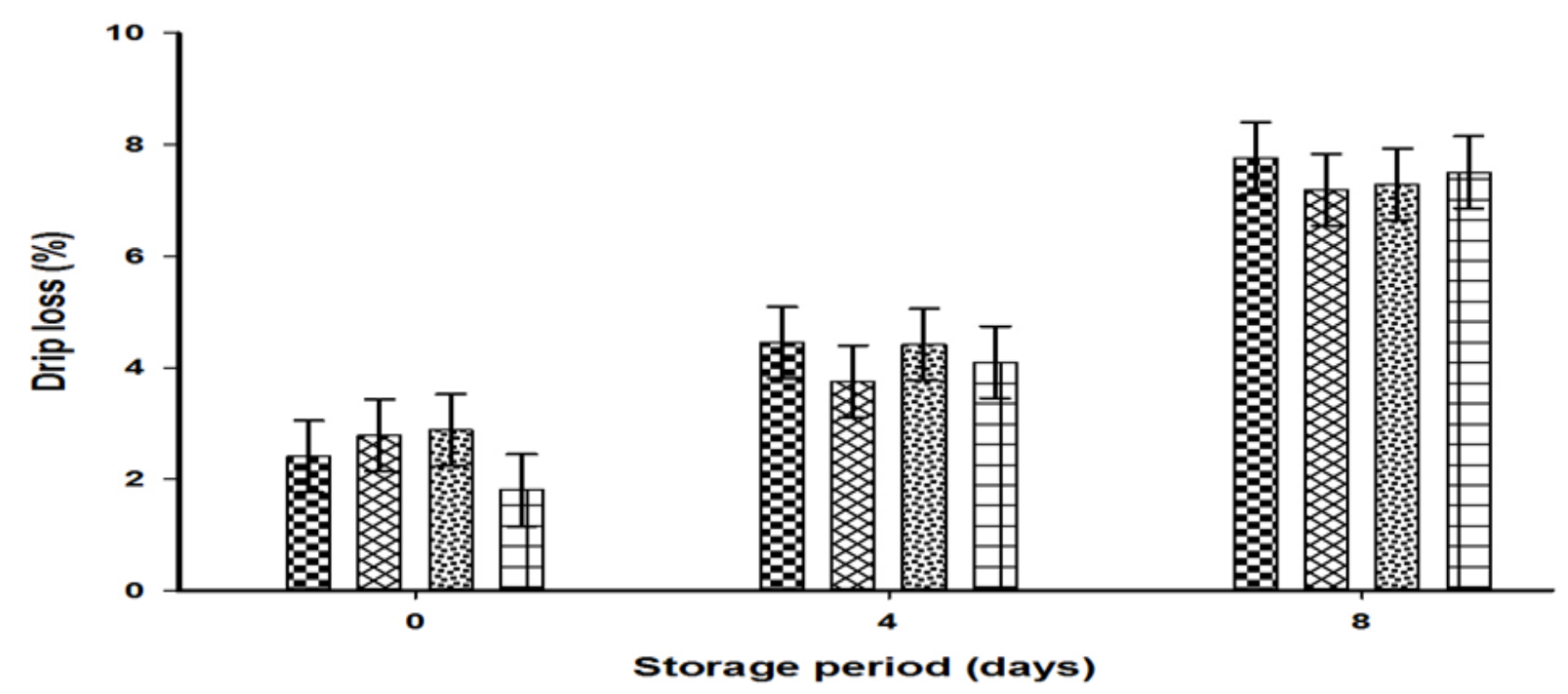

Figure 2. Interaction between subcutaneous implants of zeranol and storage period in Awassi lambs and goat meat. goat control (without zeranol) ( $B=0$ ), goat kids with zeranol ( $\square X X)$; Lambs control ( average and standard errors of differences of means 


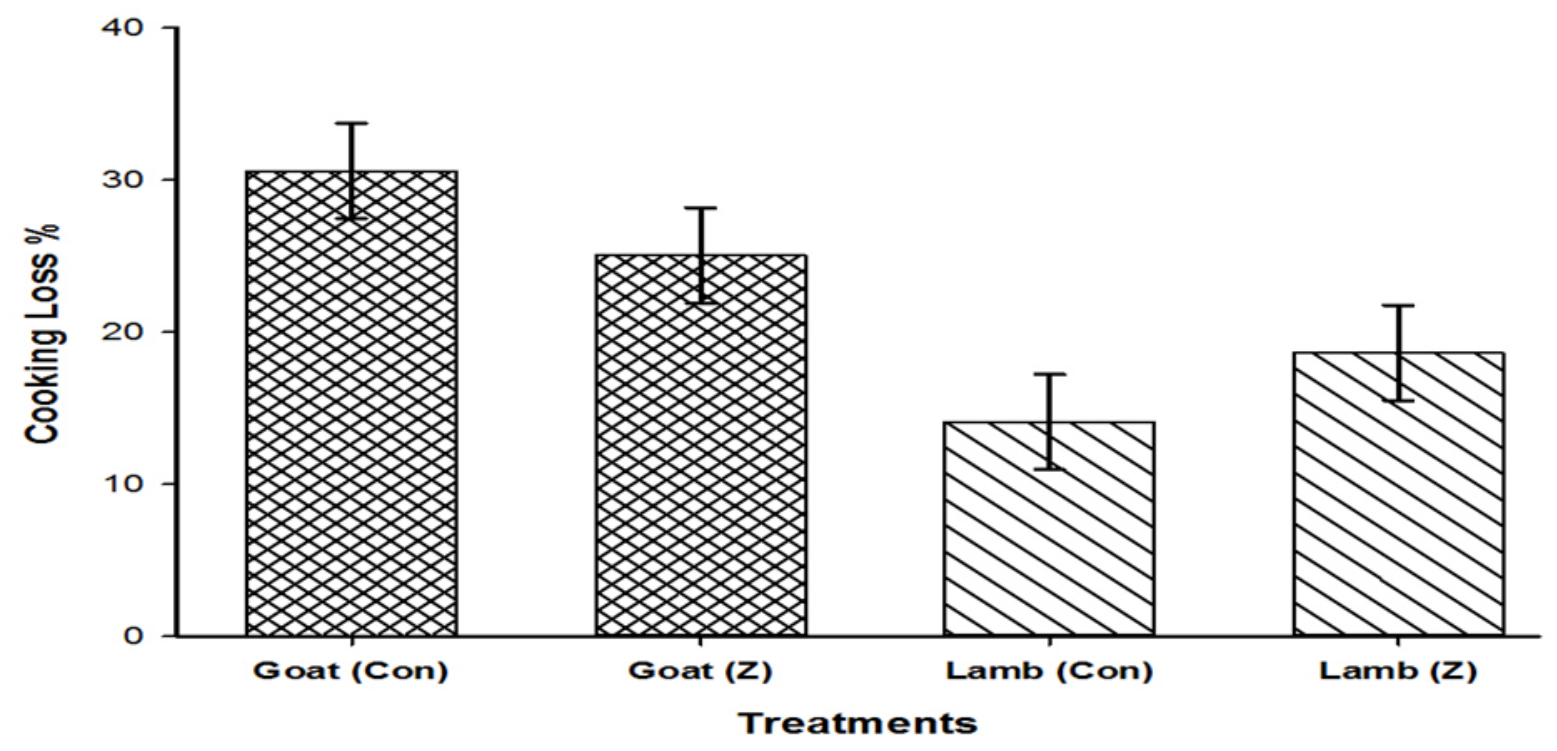

Figure 3. Effect of subcutaneous implants of zeranol on cooking loss (\%) of Awassi lambs and goat meat (Mean $\pm \mathrm{SE})$.

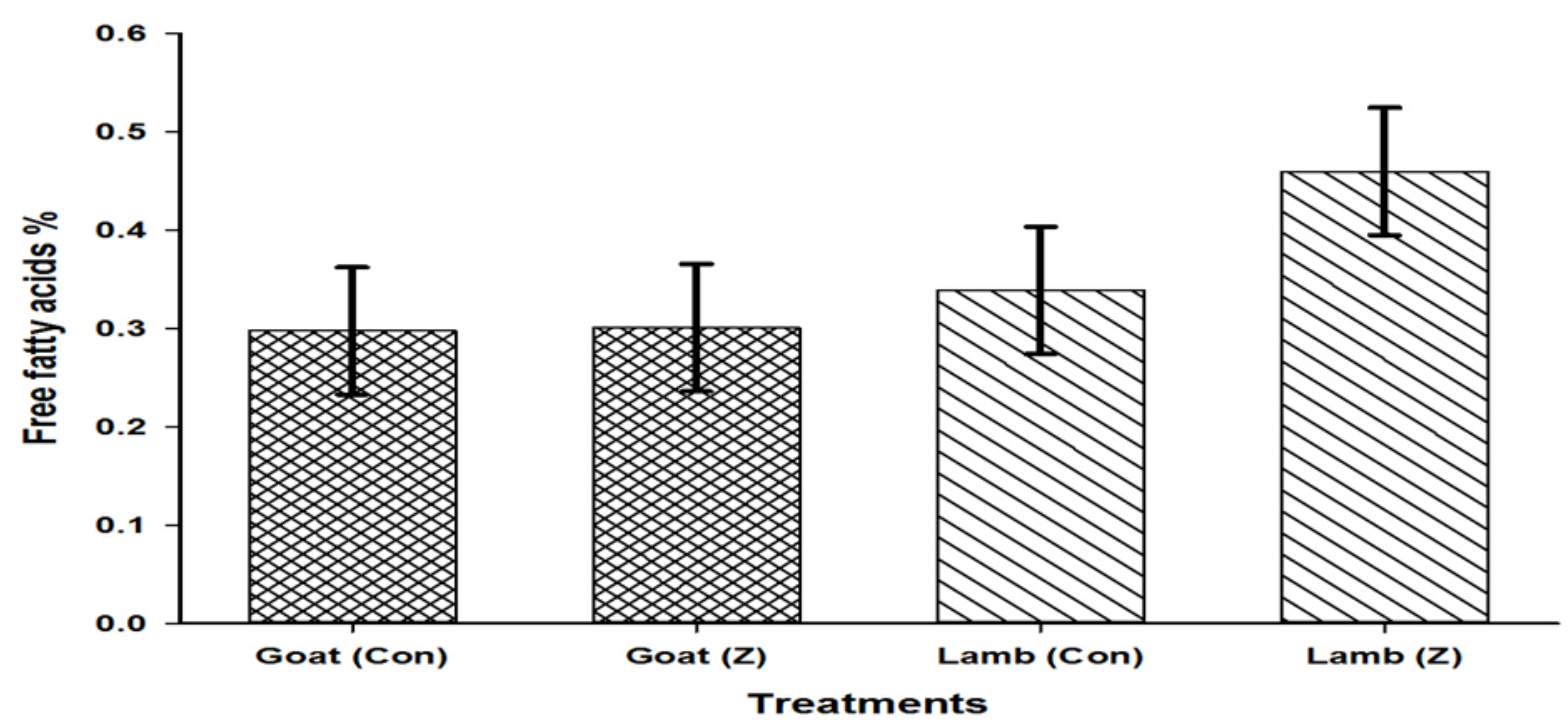

Figure 4. Effect of subcutaneous implants of zeranol on free fatty acids (\%) of Awassi lambs and goat meat (Mean $\pm \mathrm{SE}$ ).

These data indicated that zeranol implants had no effect on all meat measurements of goat kids and Awassi lambs with exception of dry matter. Significantly an increase of drip loss and TBARS value of meat from both implanted and unimplanted animals were recorded during storage period. The amount of TBARS and cooking loss were found significantly higher in Awassi lambs than goat kids. Significant effect of animal species was detecting for cooking loss, which highest values observed in goat meat than lamb meat. Similarly, significant effect of animal species was observed on TBARS values which were highest in sheep meat.

\section{REFERENCES}

1. Aaslyng, M. D., C. Bejerholm, P. Ertbjerg, H. C. Bertram, and H. J. Andersen. 2003. Cooking loss and juiciness of pork in relation to raw meat quality and cooking procedure. Food Quality and Preference, 14, 277-288.

2. Alkass, J. E. and K. H. Juma. 2005. Small Ruminants Breeds of Iraq. In Chractiraztion of Small Ruminant Breeds In West Asia and North Africa (Luis InIqueze) Vol. 1. West Asia. International center for Agriculture research in the dray Areas (ICARDA); Aleppo, Syria. 63-101. 
3. AOAC.1980. Official Methods of Analysis. $13^{\text {th }}$ Edition, Association of Official Analytical Chemists, Washington DC

4. Babiker, S. A., I.A. El Khider, and S.A. Shafie. 1990. Chemical composition and quality attributes of goat meat and lamb. Meat Science, 28(4), 273-277

5. Bax, M., L. Aubry, C. Ferreira, J. Daudin, P. Gatellier, D. Remond, and V. SanteLhoutellier. 2012. Cooking temperature is a key determinant of in vitro meat protein digestion rate: Investigation of underlying mechanisms. Journal of Agricultural and Food Chemistry, 60, 2569-2576

6. Brand, T. S., D.A. Van Der Merwe, L.C. Hoffman, and G. Geldenhuys. 2018. The effect of dietary energy content on quality characteristics of Boer goat meat. Meat Science, 139, 74-81

7. Bruns, K. W, R.H. Pritchard, and D.L. Boggs. 2005. The effect of stage of growth and implant exposure on performance and carcass composition in steers. Journal of Animal Science. 83: 108-116

8.Buege, J.A., and S.D. Aust. 1978. Microsomal lipid peroxidation methods. Enzymology. 52, $302-310$

9. Byrne, D., W.L. Bredie, L. Bak, G. Bertelsen, H. Martens, and M. Martens. 2001. Sensory and chemical analysis of cooked porcine meat patties in relation to warmedover flavour and pre-slaughter stress. Meat Science, 59(3), 229-249

10. Calder, P. C. 2015. Functional roles of fatty acids and their effects on human health. Journal of Parenteral and Enteral Nutrition, 39(1_suppl), 18S-32S

11. Castillo-López, R.I., E.P. GutiérrezGrijalva, N. Leyva-López, L.X. LópezMartínez, and J.B. Heredia. 2017. Natural alternatives to growth-promoting antibiotics (GPA) in animal production. Journal of Animal and Plant Science 27(2),.349-359

12. Cimmino, R., C.M.A. Barone, S. Claps, E. Varricchio, D. Rufrano, M. Caroprese, A. Marzia, D.P. Pasquale, C. Giuseppe, and G. Neglia. 2018. Effects of dietary supplementation with polyphenols on meat quality in Saanen goat kids. BMC Veterinary Research, 14(1) 1-11

13. Cowieson, A.J. and A.M. Kluenter. 2019. Contribution of exogenous enzymes to potentiate the removal of antibiotic growth promoters in poultry production. Animal Feed Science and Technology, 250,.81-92

14. Davis, H.E. and K.E. Belk. 2018. Managing meat exports considering production technology challenges. Animal Frontiers, 8(3),.23-29

15. Grossi, A., T. Bolumar, J. Søltoft-Jensen, and V. Orlien. 2014. High-pressure treatment of brine enhanced pork semitendinosus: Effect on microbial stability, drip loss, lipid and protein oxidation, and sensory properties. Innovative Food Science and Emerging Technologies, 22, 11-21.

16. Hayes, J.E. 2008. Sensory Descriptors for Cooked Meat Products. In Nollet, L.L, \& Toldr, F. (Eds.), Handbook of Processed Meats and Poultry Analysis (pp. 399-421). Boca Raton: CRC Press

17. Honikel, K. O.1998. Reference methods for the assessment of physical characteristics of meat. Meat Science, 49 (4), 447-457

18. Ibrahim, R. M., J.A. Marchello, and G.C. Duff. 2006. Effects of Implanting Beef Steers with Zeranol on Fatty Acid Composition of Subcutaneous and Intramuscular Fat1. The Professional Animal Scientist, 22(4), 301-306 19. Khurshid, J. S. 2016. The impact of postslaughter natural antioxidants application on the physical and chemical characteristics of broiler chicken meat. Ph. D thesis Harper Adams university.

20. Maqsood, S., A. Abushelaibi, K. Manheem, and I.T. Kadim. 2015. Characterisation of the lipid and protein fraction of fresh camel meat and the associated changes during refrigerated storage. Journal of Food Composition and Analysis, 41, 212-220. 21. Mazhangara, I. R., E. Chivandi, J.F. Mupangwa, and V. Muchenje. 2019. The Potential of Goat Meat in the Red Meat Industry. Sustainability, 11, 3671, pp 1-12

22. McKinney, K., J. Combs, P. Becker, A. Humphries, K. Filer, F. Vriesekoop. 2015. Optimization of phytase production from Escherichia coli by altering solid-state fermentation conditions. Fermentation, 1(1), 13-23

23. Min, B., K.C. Nam, J. Cordray, and D.U. Ahn. 2008. Endogenous factors affecting oxidative stability of beef loin, pork loin, and 
chicken breast and thigh meats. Journal of Food Science, 73, C439-C446

24. Montgomery, T. H., P.F. Dew, and M.S. Brown. 2001. Optimizing carcass value and the use of anabolic implants in beef cattle. Journal of Animal Science, 79(E-Suppl), E296 25. Neima, H.A., and K.M. Hassan. 2020. Trends in Livestock Production and Red Meat Industry in Sulaymaniyah Governorate, Kurdistan Region of Iraq: A Review. Journal of Animal and Poultry Production, Mansoura University: 11 (5):189 - 192

26. Rukunudin, I. H., P.J. White, C.J. Bern, and T.B. Bailey. 1998. A modified method for determining free fatty acids from small soybean oil sample sizes. Journal of the American Oil Chemists' Society, 75(5), 563568

27. Sabbioni, A., V. Beretti, E.M. Zambini, P. Superchi, and M. Ablondi. 2019. Allometric coefficients for physical-chemical parameters of meat in a local sheep breed. Small Ruminant Research, 174, 141-147

28. Thompson, J. M., B.M. McIntyre, G.D. Tudor, D.W. Pethick, R. Polkinghorne, and R. Watson. 2008. Effects of hormonal growth promotants (HGP) on growth, carcass characteristics, the palatability of different muscles in the beef carcass and their interaction with aging. Australian Journal of Experimental Agriculture
29. Tomović, V. M., M.R. Jokanović, J.V. Švarc-Gajić, I.M. Vasiljević, B.V. Šojić, S.B. Škaljac, I.I. Pihler, V.B. Simin, M.M. Krajinović, and M.M. Žujović. 2016. Physical characteristics and proximate and mineral composition of Saanen goat male kids' meat from Vojvodina (Northern Serbia) as influenced by muscle. Small Ruminant Research. 145, 44-52

30. Vestergaard, M., K. Sejrsen, J. Foldager, S. Klastrup, and D.E. Bauman. 1993. The Effect of Bovine Growth Hormone on Growth, Carcass Composition and Meat Quality of Dairy Heifers. Acta Agriculturae Scandinavica, Section A - Animal Science, 43(3), 165-172

31. Villalobos-Villalobos, G., H. GonzálezRios, F.A. Núñez-González, D. DomínguezDíaz, E.A. Peña-Ramos, and N. HuertaLeidenz. 2013. Effects of castration and zeranol on fatty acid composition and cholesterol content of hair lamb meat. Journal of Applied Animal Research, 42(1), 65-72

32. Wang, D. Y., F. Liu, and Y.Z. Zhu. 2011. Changes of phospholipids in duck muscle by different heating methods. Journal of Food Processing and Technology, 02(05), 1-5.

33. Xiong, Y. L., W.G. Moody, S.P. Blanchard, G. Liu, and W.R. Burris. 1996. Postmortem proteolytic and organoleptic changes in hot-boned muscle from grass- and grain-fed and zeranol-implanted cattle. Food Research International, 29(1), 27-34. 